\title{
MOTHERS AND DAUGHTERS: HETEROGENEITY OF GERMAN DIRECT INVESTMENTS IN THE CZECH REPUBLIC
}

\author{
Daniel Münich, Martin Srholec, Michael Moritz, Johannes Schäffler*
}

\begin{abstract}
:
Much has been written on the distinction between vertical and horizontal foreign direct investment. However, most of the empirical literature relies on indirect and aggregated measures only. The aim of this paper is to help fill this gap by examining the differences between German affiliates in the Czech Republic and their mother companies in Germany on the basis of direct evidence on factor requirements. Using a cluster analysis on firm-level data from the unique ReLOC survey, we identify four main groups of firms that partition the sample by broad sectoral lines and by technological, educational and skill intensity of their operations within each of them. More detailed analysis of the clustering reveals that the vertical model dominates in manufacturing, while the horizontal model of investment prevails in the service sector.
\end{abstract}

Keywords: multinational enterprise, foreign affiliate, vertical investment, cluster analysis, Germany, Czech Republic.

JEL Classification: D21, L16, F23, O23

\section{Introduction}

Much has been written on the distinction between vertical and horizontal foreign direct investment; for comprehensive surveys see, for instance, Barba Navaretti and Venables (2004) and Faeth (2009). But a major difficulty that besets empirical studies on this topic is the lack of relevant micro data. Most of the existing studies rely on indirect classification criteria or on aggregated proxy variables of relative factor endowments. However, these indirect measures largely leave us in the dark as regards the difference between the foreign investor, henceforth the "mother" company, and the local affiliate,

* Daniel Münich, Martin Srholec, CERGE-EI, Economics Institute, Academy of Sciences of the Czech Republic, P.O. Box 882, Politických věznů 7, 11121 Prague, Czech Republic (martin. srholec@cerge-ei.cz); Michael Moritz, Johannes Schäffler, Institute for Employment Research (IAB), Germany. Acknowledgements: Source of the microdata is the ReLOC survey led by the Institute for Employment Research (IAB) and the Center for Economic Research and Graduate Education - Economics Institute (CERGE-EI). This work has been supported by the Czech Ministry of Education, Youth and Sports (Ministerstvo školství, mládeže a tělovýchovy České republiky) by COST Project No OC09017 and by institutional support RVO: 67985998. An earlier version of the paper was presented at the 11th Comparative Analysis of Enterprise Data (CAED) \& COST Conference 2012, 26-28 April 2012, Federal Employment Agency, Nuremberg, Germany and the 7th Biennial Conference of the Czech Economic Society, 24 November 2012, University of Economics, Prague, the Czech Republic; we thank the participants at these events, Kamil Galušćák, PEP anonymous referees and the editor for helpful comments and suggestions. All usual caveats apply. 
henceforth the "daughter", in terms of their respective portfolios of activities, which is at the heart of this distinction. More detailed micro evidence directly comparing technological, educational, skill and possibly other qualities of mothers and their daughters remains extremely scarce.

The aim of the paper is to help fill this gap by empirically examining the vertical versus horizontal thesis of investment in a more direct way than the existing literature on this topic has done so far. For this purpose we organized a large survey, which collected rich original data on the activities of German daughters in the Czech Republic, their mother companies in Germany, and on the control groups of other firms in the respective countries. To our best knowledge, this is the most extensive endeavour to investigate the characteristics of German-Czech, cross-border investment. And most probably this survey is the only source of micro data that allows a direct qualitative comparison of mother and daughter companies using methodology harmonized on both sides of the border.

Germany is the second most important, only after the Netherlands, home country of direct investors in the Czech Republic. By the end of 2010, according to the CNB (2012), Germany accounted for $13.8 \%$ of the total inward stock reaching USD 17.7 billion and $8.9 \%$ of GDP. At the same time, according to Deutsche Bundesbank (2012), the Czech Republic ranks among the top ten destinations of German direct investment outside of the eurozone, ahead of such large countries as Japan, India, and Russia and figures as the most attractive destination in Central and Eastern Europe. CZSO (2012) estimates that there are about 3,500 to 4,000 affiliates of German firms in the Czech Republic, including major investors such as Volkswagen, RWE, Siemens, AEG, Continental, Linde, Deutsche Telekom, and Robert Bosch, but many small businesses must not be overlooked either. Hence, cross-border investment has, on the whole, a large impact on labour markets and economic development in both countries.

The next section briefly reviews the literature on multinational enterprises, outlines the main theoretical arguments, and draws attention to the measurement problem, particularly in light of the deepening fragmentation of production across national borders. The empirical analysis starts with a presentation of the survey and a short descriptive overview of the dataset, which highlight the main patterns. In the next step, the data are explored more analytically with the help of a cluster analysis. The results indicate that vertical investment dominates in manufacturing, whereas there is actually little difference, and hence the horizontal thesis prevails, in the service sector. Finally, the evidence is scrutinized in an econometric framework, which confirms this interpretation. The concluding section pulls the strands together.

\section{Theory, Concepts and Evidence}

Arndt and Kierzkowski (2001) identified the deepening fragmentation of production across national borders, which refers to the separation of individual activities within a value chain in space, ownership, or both, as the key distinguishing feature of the 
contemporary global economy. Some aspects of fragmentation have been earlier described as integration of trade and the disintegration of production by Feenstra (1998), "slicing up the value chain" by Krugman (1995, p. 333), or simply outsourcing by Kogut (1985). Fragmentation is not new by any means. What is unprecedented, however, is the scale and scope of this process today. The "fragmentability" of production has increased with advances in communication and transport technologies, while the scope of production networks has turned increasingly global with the liberalization of investment, trade, and with the easing of political divides between countries, of which the fall of the Iron Curtain is one of the prime examples.

An important implication of fragmentation is that firms increasingly focus on exploiting the core elements of their competitive advantage and outsource the rest. Firms grouped under the umbrella of a multinational enterprise become specialized in different fragments of production, which makes them more dissimilar to each other in terms of the portfolio of activities in which they engage in - even if they may nominally operate in the same industry. Specialization in assembly of otherwise "high-tech" electronics products is intensive on different inputs, such as cheap labour, than the design of a new generation of integrated circuits and possibly more similar to assembly activities in other lines of business. As a consequence, the particular fragments tend to gravitate towards different geographical areas matching the local endowments.

Upon the fragmentation premise builds the theoretical model of vertical direct investment established by Helpman (1984) and Helpman and Krugman (1985). Vertical multinationals locate different stages of production at home and abroad; they geographically separate fragments of the production process. The main motivation is to exploit the differences in relative factor endowments, and hence relative factor costs, as the fragments have different input requirements. Since vertical investment involves a connection in the production chain, which induces trade in inputs, this kind of investment is likely to decrease with increasing transport costs and other barriers. From this follows the "vertical thesis", according to which the mothers and their daughters specialize in a widely different portfolio of activities in terms of technological, educational, and skill intensity.

According to Eurostat's (2012) figures in 2010, hourly labour costs in the business sector were estimated at EUR 29 as compared to EUR 10, and business R\&D expenditure as the proportion of GDP amounted to nearly $2 \%$ as compared to $1 \%$ in Germany and the Czech Republic, respectively, just to briefly indicate the relative factor costs and endowments. Moreover, the geographical distance is short, transport costs are low, and formal barriers do not exist anymore. Vertical investment is expected to be directed to technologically inferior activities with the primary goal of cost saving. A typical example of vertical investment is when the mother relocates low-skilled, labour intensive production, such as assembling, from the home base to a country with lower labour costs. Arguably, the vertical model is likely to account for the bulk of direct investment from Germany to the Czech Republic. 
Yet this is not the full story. Markusen (1984), Brainard (1993), and Markusen and Venables (1998) represent pivotal contributions to the theoretical model of horizontal direct investment. Horizontal multinationals engage in the same activities in different locations. The main motivation for horizontal investment is to reduce transportation costs, or access a market that for whatever reason is not economical (or impossible) to serve from abroad; hence, this kind of investment increases with trade barriers. Another reason for investment that fits this definition but goes beyond the basic model is to move closer to foreign sources of knowledge; the investor is driven by agglomeration effects and attracted by knowledge externalities in the sense of Fujita, Krugman and Venables (1999). Either way horizontal investment is expected to appear between areas with similar factor endowments. From this follows the rival "horizontal thesis", according to which the mother duplicates a similar portfolio of activities in the daughter, generates the same kind of jobs at home and in host countries, and therefore there should not be a significant difference between them in terms of the input requirements.

The vertical thesis is consistent with the early literature on multinational enterprises, which expected technologically advanced, high-skilled, labour intensive activities to remain concentrated near the headquarters of the mother company. The idea that firms invest abroad to take advantage of assets developed in their home base is central to the "eclectic paradigm" by Dunning (1981), is implicit in the model of multinational business presented by Caves (1971), and can be even traced back to the product cycle theory of international technology diffusion by Vernon (1966). According to this view, the daughters are expected to engage in any sort of advanced activities, such as research and development (R\&D), only if necessary to facilitate the implementation of technology developed at the home base and only for the purpose of utilizing already existing assets.

Nevertheless, more recent literature postulates that dispersion winds for the location of advanced activities are in place as well. The traditional perspective has been challenged by the observation of Kogut and Zander (1993) that the technological bases of multinational enterprises are increasingly not limited to any single country but rather emerge from a variety of sources on a global scale. Cantwell (1995) argues that firms need to invest in $\mathrm{R} \& \mathrm{D}$ abroad to tap into technology competencies embedded in foreign locations. At the heart of this perspective is the argument that important aspects of technology are tacit and "sticky", which makes them less costly (or otherwise impossible) to transfer within a firm's ownership boundaries rather than through market transactions. Hence, a horizontal investment of R\&D-intensive mothers to R\&D-intensive daughters is likely.

Dunning and Narula (1995) and Kuemmerle (1997) dubbed the former reasons asset (or home base) exploiting motives, while the latter have been labelled as asset (or home base) augmenting motives. It is important to realize, however, that the host country needs to reach a certain minimum threshold of location-specific technology factors such as a pool of highly educated labour, specialized suppliers, and a state-of-the-art scientific infrastructure, access to which foreign firms seek to internalize, to attract the augmenting investment in order for the investors to go beyond the cheap labour exploiting strategy. 
Even if multinationals develop networks of augmenting daughters in multiple locations, this kind of investment is likely to be concentrated in a relatively limited number of technologically advanced areas particularly near the headquarters of rival multinational enterprises.

Overall, the existing evidence indicates that the vertical model accounts for a much larger share of German direct investment in Central and Eastern Europe than in other major destinations. Buch, Kleinert, Lipponer and Toubal (2005), based on a firm-level data set of about 8,800 German foreign affiliates worldwide from the Deutsche Bundesbank and aggregate data from other sources, found that the horizontal market access motive is predominant, but they regarded the vertical cost saving motive to be frequent in some manufacturing sectors and suggested that this motive is likely to play a particularly prominent role in transition economies; however, unfortunately few specifics were said about the Czech Republic in this study.

Marin, Lorentowicz and Raubold (2003) conducted a survey among the top managers of German investors in Central and Eastern Europe which provided data from a sample of 420 firms with 1,050 investment projects where nearly a quarter was located in the Czech Republic. Using information on the proportion of inputs imported from the mother company and sales exported back to the mother, they found strong evidence for the vertical model suggesting that the investors are, by and large, outsourcing production to exploit lower wages in this region. But the intensity on intra-firm trade appeared relatively low in the Czech Republic, on the basis of which they concluded that specifically in this country horizontal investment dominates.

Looking more closely at the Czech data from the same survey, however, Protsenko (2003) reached a somewhat different conclusion. He classified an investment project as vertical if trade with the mother accounted for more than $50 \%$ of either the inputs or sales of the daughter, respectively. All other projects were classified as horizontal. On the basis of these criteria, the vertical model accounted for $60.3 \%$ of the investment projects, but as a consequence of several very large investments in the financial and automotive sectors, only for $23.3 \%$ of the amount of investment. Hence, there were major outliers driving the total figures.

Marin (2006) reconsidered the previous findings in a follow-up paper that concentrated on the identification of offshoring, defined as a relocation of activity abroad that remains inside the firm, thus essentially the vertical model. Offshoring investment was deemed to be a project that both imports input goods from the mother and exports the output back after refinement at the same time, regardless of the amount of trade. About $76 \%$ of German projects in the Czech Republic were classified in the offshoring category, but she noted that using a slightly tighter criterion that required at least $20 \%$ of sales directed back to the mother, the proportion of offshoring projects in the Czech Republic were reduced to $10 \%$ only. Hence, the results seem extremely sensitive to the threshold. 
Görg, Mühlen and Nunnenkamp (2010) used micro data from the German-Czech Chamber of Industry and Commerce, but for a lack of relevant variables, the classification of investment by type must have relied on information about the industry. Based on a comparison of the indexes of the revealed comparative advantage derived from bilateral trade between Germany and the Czech Republic and the principal activity of the German mother at the 3-digit NACE level, they classified 177 projects as vertical and 284 cases as horizontal, while based on the (mis)match between the reported principal activity of the mother and the daughter at the 2-digit NACE level, they identified 284 vertical and 194 horizontal projects; they gave more weight to the first result. In any case, the evidence seems to be mixed with roughly $60 \%$ to $40 \%$ proportion in favour of one or the other type of investment depending on the measure.

Gauselmann, Knell and Stephan (2011) reported evidence on the foreign investment projects in Central and Eastern Europe, including 185 cases in the Czech Republic, based on the IWH-FDI-Micro database. Even though they do not explicitly consider the vertical versus horizontal dichotomy and do not focus on German investors, this paper deserves to be mentioned here because the survey provides rare evidence on the strategic motives of investors. The main finding is that the motive of tapping localized technology is significantly more important in the Czech Republic compared with other countries, and that managers of the Czech daughters are significantly more satisfied with the potential for technological cooperation with local science institutions than elsewhere in the region.

From this follows that the Czech Republic seems to be an attractive destination for both vertical and horizontal investment of German firms; the share of vertical investment is probably high in the German-Czech, cross-border context by international standards although the augmenting modus operandi of the Czech daughters cannot be ruled out either. But the micro evidence is scant, limited to a handful of papers, which employ hardly any comparable methodologies, and most importantly, the results with regards to the relative share of both the vertical and horizontal models differ by a large margin, even if based on the same source of data. Hence, the existing literature is ambiguous, and the lack of thorough evidence begs for more examination.

Admittedly, a major reason for limited progress in empirical research along these lines, despite much theoretical reasoning, is the lack of relevant micro data. Official statistics do not differentiate between the types of investors, and hence, researchers interested in this topic either collect data by independent surveys, which suffer from low response rates; merge data from various sources, which often results in a massive loss of observations; and/or rely on poor proxy variables to identify the distinction; not to mention the studies that resort to using aggregate or industry-level data that completely ignore the underlying micro heterogeneity.

Buch, et al. (2005), for instance, rely on the assumption that the investment is horizontal if the daughter operates in the same industry abroad as the mother at home and vertical otherwise. At first, this method sounds appealing, but as Görg, et al. (2010) also realized, this hinges on the level of aggregation. The share of horizontal investment is overstated 
if the aggregation is too high, and the opposite bias is likely if the distinction is based on a very detailed classification as the principal activity of the mother and daughter can be very similar but categorized in nominally different, possibly neighbouring industry codes. Moreover, the principal activity of both the mother and daughter needs to be correctly recognized, but this is well-known to be difficult for large, multi-plant and multi-product firms, typically multinational enterprises. Further, this criterion ignores intra-industry differences in quality, and thus in endowment requirements, which are central to the distinction.

Another way to identify vertical investment that has been already mentioned is to obtain information on intra-firm trade, namely the import of intermediate goods from the mother to the daughter and the output of the daughter purchased by the mother, assuming that this kind of trade involves a connection between different fragments of production. Surely, intra-firm trade is a symptom of fragmentation, and hence signals the vertical model, but fragmentation goes much beyond investment. Production is fragmented not only in space but also in ownership; multinational enterprises not only offshore but also outsource, and not only the mother but also other suppliers become entangled with her daughters in production networks. If the vertical linkage between the mother and daughter is indirect, if other firms process the inputs along the route between them, the daughter becomes classified as horizontal according to this criterion even though the investment project is a textbook example of the vertical case.

Available evidence on the global spread of production networks indicates that looking solely at intra-firm trade to identify the distinction is likely to entail a severe downward bias in the extent of vertical investment. Ernst and Kim (2002) and Gereffi, Humphrey and Sturgeon (2005) point to the fact that multinational enterprises increasingly operate as flagships of extended production networks, part of which they directly own, but which also comprises independent suppliers affiliated to the network by long-term contracts, such as the original equipment manufacturing framework. As a result, the production network becomes a complex matrix of input-output relationships spanning far outside of the mother's group; intermediate goods streaming along the route. This blurs the distinction of what is an internal and external exchange.

Furthermore, considering the import of intermediate goods, typically processed materials, industrial supplies, and manufacturing components, grossly underestimates the vertical investment in the service sector. Although the offshoring of services is relatively new, multinational enterprises increasingly relocate activities abroad, such as call centres, accounting and information services, which involve little or no exchange in intermediate goods between the mother and daughter. All that matters, of course, how the question is specified in the survey, but typically firms are asked about the import of goods only, not covering service procurement, as the latter is far more difficult and possibly sensitive to report. It might well be that a good part of what has been deemed horizontal investment in the data used by Marin, et al. (2003), Protsenko (2003) and Marin (2006), which includes daughters both in manufacturing and services, actually refers to a vertical relocation of services. 
Görg, et al. (2010) in concordance with many studies based on aggregate data used wages to proxy for skill intensity. But average wage is a crude measure of factor requirements because the wages of all skill categories of workers can be relatively high in a particular firm, industry, or country for reasons independent of skills, such as collective bargaining, market structure and macroeconomic conditions. Using wage differences to infer the type of project rests on the assumption that horizontal investors pay equivalent wages for the same kind of jobs at home and in the host country, which is clearly elusive and defeats the purpose. After all, using the wage differential would probably lead us to conclude that the vast majority of German-Czech investment is vertical, just because there is a large aggregate wage difference, even if adjusted by purchasing power parity.

As documented by Blomström and Kokko (1998), there is, furthermore, extensive literature on the possibility of various spillover effects between foreign affiliates and the host economy. Despite strong theoretical reasons to expect spillovers, however, the evidence is mixed at best. Görg and Greenaway (2004) point out that the empirical literature, typically using indirect measures of technology in the production function framework, finds strong support for direct technology transfer from the parent to the foreign affiliate, but evidence for technology spilling over to the host country is rare, and rather, the crowding out of non-affiliated firms is often detected. Stancik (2007) confirms that domestic companies tend to be negatively affected by the presence of foreign companies in the Czech Republic, especially in upstream sectors. However, Havranek and Irsova (2011) testify for the fact that the more recent literature focusing on vertical spillovers tends to be somehow more positive in this respect. A more direct measurement of the distinction between horizontal and vertical, not simply based on the industry classification of the firms, can also prove fruitful for tackling the spillovers issue.

\section{An Overview of the Dataset}

The empirical analysis is based on original micro (firm) level data collected by the "Research on Locational and Organisational Change" (ReLOC) survey. First, we identify firms involved in offshoring, hence those firms which carry out their activities in-house abroad and their foreign business units. Next, these firms are compared with a control group of companies without foreign direct investment. From this four survey groups were identified:

(T_CZ) Treatment group in the Czech Republic: German daughters, which refer to firms registered in the Czech Republic owned by German companies. By combining information on ownership from the Creditinfo database, the Čekia database, the GermanCzech Chamber of Industry and Commerce, and the Czech Commercial Register 3,875 
relevant survey participants have been identified. ${ }^{1}$ If there were two or more German affiliates which had the same residence and owner, only one, randomly drawn, had been included in the survey. After this reduction 3,651 affiliates had been selected for the survey. Moreover, based on information collected in the survey, we are able to distinguish the mode of entry: i) Greenfield daughters (T_CZ1) had German owners from the outset, while ii) Merger \& acquisition (M\&A) daughters (T_CZ2) acquired German owners sometime during their lifetime.

(C_CZ) Control group in the Czech Republic: Firms registered in the Czech Republic, which are purely Czech-owned; they neither have a direct nor an indirect foreign owner. Czech companies which did not have foreign owners but where other Czech firms with foreign owners held shares in them were also excluded. The information concerning the existence of a foreign owner was obtained from the Creditinfo database and additionally checked with each company before conducting an interview.

(T_DE) Treatment group in Germany: German mothers, which are firms registered in Germany with an affiliate in the Czech Republic. The starting point is the German owners of the 3,875 companies in the Czech treatment group of which 3,274 were selected for the survey after identifying their full address. There are less mothers than daughters because some German owners were involved with more than one Czech company.

(C_DE) Control group in Germany: Firms registered in Germany, which did not have a foreign affiliate. This information was derived from the database of Heins \& Partner and additionally checked with each company before conducting an interview.

The survey was conducted by TNS Infratest Sozialforschung in Germany and by TNS AISA in the Czech Republic from September 2010 to May 2011. The data were collected via personal interviews using written questionnaires. The sampling frame was a census of the total population of mothers and daughters ( $\mathrm{T}_{-} \mathrm{CZ}$ and $\left.\mathrm{T}_{-} \mathrm{DE}\right)$ and a sample stratified by industry and number of employees of the two control groups (C_CZ and C_DE); the latter were stratified to match the composition of the respective treatment group, which meant comparable data for the groups within each country were obtained. For more details on the survey methodology see Hecht, Litzel and Schäffler (2013).

Excluding companies which were identified as not existing anymore, not reachable, or did not exhibit the characteristics of the respective group when contacted, the response rates were $14.9 \%$ in the Czech treatment group, $12.9 \%$ in the Czech control group,

1 As a basic principle, we only considered daughters which were either legally connected to a German company or where there was a legal connection between a German company and its owner.

Therefore, not all of the 5,700 Czech firms with German owners turned out to be relevant to the survey because nearly half of them were not directly owned by a German firm but by a German private individual, of which only daughters with a German individual owner who also owned at least one German firm were considered. However, the database remains much larger in comparison with other sources. For example, the Amadeus database of Bureau van Dijk contained only 1,150 Czech companies with German owners in the February 2011 edition. In particular, smaller affiliates have been grossly under-represented in previous studies. 
$18.5 \%$ in the German treatment group and $19.1 \%$ in the German control group. It is well acknowledged that the representativeness of the data is a thorny issue. Yet we should not judge this data by the standards of official surveys, answering to which is often compulsory by law. Moreover, the survey brings unique detailed evidence on the operation of mother and daughter companies, for which micro data remain extremely scarce, and the few original surveys on this topic that have been conducted previously ended up with similar or even much worse response rates. ${ }^{2}$

The size of the firm is measured by the total headcount of employees, excluding agency and other external workers, in June 2010. The age of the firm refers to the number of years since the firm has been established in the respective country. The industry affiliation is identified by the self-reported principal activity of the firm, the structure of which broadly corresponds to the Statistical Classification of Economic Activities (NACE, rev. 2). On the basis of this information, we derive a broad sectoral dummy variable with the value 1 for firms classified in the mining, manufacturing, and utility sectors, henceforth "manufacturing" for simplicity, and with the value 0 for firms operating in the service sector, i.e. 05-39 and 41-96 categories at the 2-digit level of NACE, rev. 2, respectively.

Besides the traditional information on the industry, firms further identified their position in the value chain, which provides us with an insight about the primary activity of the firm from a different angle. Firms were asked to classify themselves on a seven-point scale ranging from 1 for activities at the beginning of the chain, such as the extraction of raw materials, product design and prototype testing, to 7 representing the final stage, when the product or service is delivered to the consumer with the total value-added increasing in a snowball manner along the route. Hence, we are able to see how far the firm operates from the final user.

Structural patterns like these are relevant, but even more important is to have direct evidence on the underlying factor requirements. $R \& D$ is the traditional and for a long time the only seriously considered data on investment in technology. Firms were asked to identify whether R\&D belongs to major business functions conducted by the company, which can be perhaps interpreted as the presence of an internal R\&D department. From this follows a dummy variable with the value 1 for firms that answered affirmatively and with the value 0 otherwise. The purpose of this variable is to capture a general commitment of the firm to R\&D activity.

Next, the respondents were asked to evaluate the technological level of their company in terms of the physical equipment, i.e. production lines, machinery, tools, etc. in comparison with other firms in the same industry on a seven-point Likert scale ranging from -3 for absolutely obsolete, 0 for the average level, to +3 indicating state-of-theart technology. Indeed, this variable gives us an invaluable insight about the perceived

2 See, for instance, the IWH-FDI-Micro database of foreign investors that has been collected by telephone interviews; it is based on a response rate of about $10 \%$ in the Central and East European countries (Günther, et al. 2011). Another example is the "Going International survey", a postal survey carried out by the "Deutscher Industrie- und Handelskammertag" with a response rate of $8 \%$ only (Buch, et al. 2007). 
technological position of the firm vis-à-vis direct competition, and hence hints on the business strategy, whether the firm is a technology leader or rather a follower, and whether the firm competes on quality or rather on low costs.

Yet the factor endowment of the firm is about more than just spending on R\&D and modern machinery; so, we need to keep an eye on broader indicators, too. For this purpose the data on educational attainment (or qualification) of employees, which represent a rough proxy of human capital, come in as handy. More specifically, the respondents were asked to divide their labour force into three broad categories as follows: i) Low educated labour, which refers to employees, who conduct simple activities not requiring specialized education/training; ii) Medium educated labour, referring to employees, who conduct qualified work, for which vocational education or equivalent specialized training and job experience are required; and iii) Highly educated labour, which refers to employees, who conduct qualified work, for which tertiary education is necessary.

And even better, following Acemoglu and Autor (2011), the firms were asked to evaluate the skill requirements of the tasks actually performed by the employees; they reported the percentage share of different kinds of tasks involved in the process, in which the main product or service is produced. Five task categories were distinguished: i) Routine manual tasks, which refer to manual work consisting of simple repetitive operations, for example packaging, sorting, copy making, etc.; ii) Non-routine manual tasks, which refer to manual work not consisting of simple repetitive operations only but also including operations that require reactions to changes of the working conditions, for example driving, maintenance, serving in restaurants, etc.; iii) Routine non-manual tasks, which consist of simple repetitive operations, for example proofreading, measurement, bookkeeping, etc.; iv) Interactive tasks, which do not consist of simple repetitive operations, for example negotiating, consultancy, or lecturing; and v) Analytical tasks, which refer to operations that are not repetitive and require innovative solutions and independent thinking of the employee, such as research, evaluation, planning.

After omitting observations with missing data on either of these questions, we have at our disposal a sample of 350 German daughters in the Czech Republic (T_CZ), of which 264 are greenfield (T_CZ1) and 86 M\&A (T_CZ2), 662 firms in the Czech control group (C_CZ), 364 German mother companies in Germany (T_DE), and 1,065 firms in the German control group (C_DE); hence, the total sample consists of 2,441 observations.

Table 1 provides the mean values of the variables. About half of the total sample and a bit more than half of the mothers and daughters operate in manufacturing. More than two-thirds of the mothers but only about every fourth to fifth daughter engage in R\&D. Also in line with expectations the mothers dominate in terms of the technological level of their equipment; they are positioned more upstream in the value chain, and they are much larger than the rest of the sample. However, the greenfield affiliates surprisingly come out with the highest share of the top category of educational attainment; this can be perhaps attributed to the well-known problem that diploma counts do not satisfactorily measure quality. Admittedly, the task complexity variables are more informative in this respect. A more detailed discussion of these differences is presented in the next section. 
Table 1

Mean Values by Location and Ownership of the Firms

\begin{tabular}{|c|c|c|c|c|c|c|}
\hline Location & \multicolumn{3}{|c|}{ Czech Republic } & \multicolumn{2}{|c|}{ Germany } & \multirow{3}{*}{ Total } \\
\hline \multirow[t]{2}{*}{ Ownership } & $\begin{array}{c}\text { Greenfield } \\
\text { daughter }\end{array}$ & $\begin{array}{c}\text { M\&A } \\
\text { daughter }\end{array}$ & $\begin{array}{l}\text { Control } \\
\text { group }\end{array}$ & Mother & $\begin{array}{l}\text { Control } \\
\text { group }\end{array}$ & \\
\hline & (T_CZ1) & (T_CZ2) & (C_CZ) & (T_DE) & (C_DE) & \\
\hline \multicolumn{7}{|c|}{ General characteristics: } \\
\hline Number of employees & 60.5 & 131.6 & 62.7 & 264.8 & 155.5 & 135.5 \\
\hline Age & 12.8 & 17.3 & 16.3 & 45.3 & 46.8 & 33.6 \\
\hline Manufacturing & 56.1 & 70.9 & 47.9 & 56.0 & 40.4 & 47.5 \\
\hline \multicolumn{7}{|c|}{ Value chain position: } \\
\hline 1: Upstream & 1.1 & 0.0 & 0.8 & 0.8 & 1.7 & 1.2 \\
\hline 2 & 2.3 & 1.2 & 2.4 & 4.4 & 3.5 & 3.1 \\
\hline 3 & 7.2 & 9.3 & 5.0 & 9.6 & 5.7 & 6.4 \\
\hline 4: Middle & 18.2 & 7.0 & 13.6 & 27.2 & 16.3 & 17.1 \\
\hline 5 & 23.1 & 29.1 & 18.9 & 25.3 & 18.9 & 20.6 \\
\hline 6 & 23.1 & 24.4 & 20.2 & 20.1 & 21.6 & 21.3 \\
\hline 7: Downstream & 25.0 & 29.1 & 39.1 & 12.6 & 32.3 & 30.3 \\
\hline \multicolumn{7}{|c|}{ Intramural R\&D activity: } \\
\hline R\&D engagement & 18.6 & 26.7 & 23.3 & 67.3 & 28.5 & 31.7 \\
\hline \multicolumn{7}{|c|}{ Quality of equipment: } \\
\hline -3: Absolutely obsolete & 1.9 & 2.3 & 0.9 & 0.3 & 0.7 & 0.9 \\
\hline-2 & 6.4 & 2.3 & 3.0 & 1.6 & 1.7 & 2.6 \\
\hline-1 & 6.1 & 10.5 & 7.1 & 4.1 & 4.5 & 5.5 \\
\hline 0 : Average & 32.6 & 23.3 & 28.4 & 14.6 & 12.2 & 19.5 \\
\hline 1 & 23.5 & 23.3 & 29.5 & 22.3 & 21.5 & 24.0 \\
\hline 2 & 19.3 & 33.7 & 24.6 & 42.3 & 41.6 & 34.4 \\
\hline 3: State-of-the-art & 10.2 & 4.7 & 6.5 & 14.8 & 17.8 & 13.0 \\
\hline \multicolumn{7}{|c|}{ Education attainment of employees: } \\
\hline Low educated labour & 20.4 & 23.5 & 18.2 & 21.3 & 22.3 & 20.9 \\
\hline $\begin{array}{l}\text { Medium educated } \\
\text { labour }\end{array}$ & 46.9 & 57.4 & 58.8 & 60.5 & 67.3 & 61.4 \\
\hline Highly educated labour & 32.7 & 19.1 & 23.0 & 18.2 & 10.4 & 17.7 \\
\hline \multicolumn{7}{|c|}{ Task complexity: } \\
\hline Routine manual tasks & 31.4 & 39.3 & 25.2 & 25.5 & 29.0 & 28.1 \\
\hline $\begin{array}{l}\text { Non-routine manual } \\
\text { tasks }\end{array}$ & 20.0 & 27.9 & 33.9 & 20.5 & 26.5 & 27.0 \\
\hline $\begin{array}{l}\text { Routine non-manual } \\
\text { tasks }\end{array}$ & 12.8 & 13.6 & 14.1 & 16.3 & 13.1 & 13.8 \\
\hline Interactive tasks & 19.0 & 10.5 & 14.9 & 20.8 & 18.7 & 17.7 \\
\hline Analytical tasks & 16.9 & 8.7 & 11.9 & 16.9 & 12.7 & 13.4 \\
\hline Number of observations & 264 & 86 & 662 & 364 & 1,065 & 2,441 \\
\hline
\end{tabular}




\section{Cluster Analysis}

To find distinct groups of firms with regards to the factor requirements, we divide them with the help of a cluster analysis according to the type of business activity, technology, education, and skill variables. Hierarchical clustering, more specifically the method of complete linkage, is used because the decision on the number of clusters to be retained is not required beforehand, which is preferable for solving the problem at hand. Since the dataset includes binary, ordinal, and continuous variables, we use Gower's dissimilarity coefficient in the clustering procedure, which is suitable for a mix of data on different scales. For more details see Stata (2009a).

Calinski and Harabasz (1974) and Duda, Hart and Stork (2001) developed rules for stopping the hierarchical clustering procedure that can be used to determine the number of clusters. Higher values of the Calinski-Harabasz pseudo-F index and smaller values of the Duda-Hart pseudo-T-squared statistics indicate more distinct clustering. Table 2 presents the results. Four or three clusters appear as the most viable solution. Also this partitioning of the data appears to be consistent with the dendrogram. After inspecting the results more closely, we have chosen to retain four clusters because, in our view, this solution more credibly represents the main characteristics of the sample. ${ }^{3}$

\section{Table 2}

\section{Cluster Analysis Stopping Rules}

\begin{tabular}{|l|c|c|}
\hline \multirow{2}{*}{$\begin{array}{l}\text { Number } \\
\text { of clusters }\end{array}$} & Calinski/Harabasz & Duda/Hart \\
\cline { 2 - 3 } & pseudo-F & Pseudo T-squared \\
\hline $\mathbf{2}$ & 66.33 & 161.60 \\
\hline $\mathbf{3}$ & 132.87 & 9.00 \\
\hline $\mathbf{4}$ & 91.12 & 6.30 \\
\hline $\mathbf{5}$ & 70.56 & 158.32 \\
\hline $\mathbf{6}$ & 91.70 & 55.05 \\
\hline $\mathbf{7}$ & 83.53 & 116.98 \\
\hline $\mathbf{8}$ & 96.45 & 100.29 \\
\hline $\mathbf{9}$ & 98.72 & 92.15 \\
\hline $\mathbf{1 0}$ & 102.73 & 67.42 \\
\hline
\end{tabular}

3 Since the categories of education attainment on the one hand and task complexity on the other hand represent linear combinations of each other, i.e they add together to $100 \%$, we exclude the most frequent categories of "Medium educated labour" and "Routine manual tasks" from the clustering procedure. 
Table 3

Mean Values by Cluster

\begin{tabular}{|l|c|c|c|c|c|}
\hline \multirow{2}{*}{ Variable } & \multicolumn{3}{|c|}{ Cluster } & \multirow{2}{*}{ Total } \\
\cline { 1 - 5 } & $\begin{array}{c}\mathbf{1} \\
\text { High-tech } \\
\text { manufacturing }\end{array}$ & $\begin{array}{c}\mathbf{2} \\
\text { Low-tech } \\
\text { manufacturing }\end{array}$ & $\begin{array}{c}\mathbf{3} \\
\text { High-tech } \\
\text { services }\end{array}$ & $\begin{array}{c}\mathbf{4} \\
\text { Low-tech } \\
\text { services }\end{array}$ & \\
\hline Manufacturing & 1.00 & 1.00 & 0.00 & 0.00 & 0.48 \\
\hline Value chain position & 4.98 & 5.31 & 5.08 & 5.97 & 5.38 \\
\hline R\&D engagement & 1.00 & 0.00 & 0.38 & 0.00 & 0.32 \\
\hline Quality of equipment & 1.32 & 0.87 & 1.57 & 1.06 & 1.19 \\
\hline Low educated labour & 23.9 & 25.8 & 6.8 & 25.3 & 20.9 \\
\hline Medium educated labour & 61.5 & 62.7 & 54.3 & 65.7 & 61.4 \\
\hline Highly educated labour & 14.6 & 11.6 & 38.9 & 9.1 & 17.7 \\
\hline Routine manual tasks & 34.2 & 41.5 & 10.7 & 25.6 & 28.1 \\
\hline Non-routine manual tasks & 26.2 & 30.1 & 18.0 & 31.7 & 27.0 \\
\hline Routine non-manual tasks & 14.5 & 11.3 & 14.9 & 14.5 & 13.8 \\
\hline Interactive tasks & 12.5 & 8.9 & 28.7 & 20.7 & 17.7 \\
\hline Analytical tasks & 12.7 & 8.2 & 27.7 & 7.5 & 13.4 \\
\hline Number of observations & 567 & 593 & 550 & 731 & 2,441 \\
\hline
\end{tabular}

Table 3 gives mean values on the variables in the four principal clusters. The main dividing line runs on the one hand between principally manufacturing and service firms and on the other hand between firms that score high and low on the technology, educational, and skill variables. From this follows the distinction of high- versus low-tech categories of firms operating in manufacturing and services, respectively:

\section{Cluster (1): High-tech manufacturers}

The first cluster identifies manufacturing firms, each of which conducts R\&D activity and which maintain more highly educated labour, require a higher share of employees performing interactive and analytical tasks, and furnish themselves with technologically more advanced equipment compared to firms classified in the inferior manufacturing category. All in all, this earns them the status of the "High-tech manufacturing" category.

\section{Cluster (2): Low-tech manufacturers}

The second group marks manufacturing firms on the opposite side of the technological spectrum, which do not engage in $R \& D$, have a less educated workforce, specialize in manual work, especially the most rudimentary routine tasks, and use more technologically outdated equipment than in any of the retained groups; hence, this is the "Low-tech manufacturing" cluster. 


\section{Cluster (3): High-tech service providers}

The third cluster lumps together advanced service firms, which have by far the most educated labour, the best tasks complexity portfolio and cutting-edge equipment; they even outclass in these characteristics the high-tech manufacturing firms, and by a large margin. Hence, this group comprises the real boon in technology and, hence, clearly deserves to be placed in the "High-tech services" rubric.

\section{Cluster (4): Low-tech service providers}

Finally, there is a fourth group, which is the reverse mirror image of the previous category, so that the label of "Low-tech services" fits rather well.

Also the value chain position confirms this interpretation. As can be expected, firms classified in manufacturing consider themselves more upstream than in services, if one compares the respective high- and low-tech clusters with each other because many more service firms, by the nature of their business, operate close to the final customer. But there is a difference by the cluster solution within sectors, too. Low-tech firms are considerably more downstream, which reflects the fact that value chain segments that are particularly intensive on high-skilled labour, including various professional, engineering and research activities, come early in the value chain, whereas segments that require relatively low-skilled labour, such as assembling, sales or distribution, appear down the route.

Another outcome that needs to be clarified is that less than half of firms classified in the high-tech services category reported any engagement in R\&D. According to the definition of the OECD (2002), however, there are many jobs which either do not meet the formal criteria of what is considered to be $\mathrm{R} \& \mathrm{D}$, even though they are closely related to it such as all sorts of educational, measuring and testing services, or oscillate at the borderline of what should (not) be included such as those in the domain of consultancy, software development, and market research. Hence, there can be a downward measurement bias in the R\&D question particularly for firms operating in the service sector.

All of the clusters are frequently populated, none of them dominate in terms of the number of observations, and none of them represent a mere residual category, which confirms that each of the groups has a merit in its own right. If we retain several more clusters, mixed groups of firms start appearing in manufacturing and services. But this involves partitioning the sample into too many groups, some of which are sparsely populated, and hence, difficult to work with empirically. So there seem to be pockets of firms that, given the characteristics taken into account, cut across the traditional dichotomy between manufacturing and services. Unfortunately, however, the data in hand do not allow us to say much about them.

Table 4 reports the clustering results by ownership and location of the firms, which is at the heart of the interest in this paper. Not surprisingly, the mother companies are by far the most advanced as about half of them belong to the high-tech manufacturing cluster; 
more than one-fourth of them concentrate in the high-tech services cluster, and only about every fifth of them are classified as low-tech either in manufacturing or services. Of course, the technological superiority of mothers is one, if not the primary, reason why they venture into investing abroad in the first place. More interesting is, therefore, to compare this outcome to the distribution of daughters, and here the distinction between manufacturing and services comes out strong.

Daughters in manufacturing seem to be a reverse mirror image of the mothers as by far the most prevalent category is the low-tech manufacturing cluster; with little difference between greenfield and M\&A investment projects, thus the technological superiority of the mothers does not translate into the operations of the daughters. In fact, quite the opposite seems to be the case because the manufacturing daughters are concentrated in the low-tech segment even more than the control group. Hence, the data indicate that in manufacturing there is a clear vertical division of labour between the mothers and daughters, in which the former specialize in technologically intensive activities, while the latter operate at the low end of the spectrum.

Table 4

Percentage Distribution of the Location and Ownership Categories by Cluster

\begin{tabular}{|l|l|l|r|r|r|r|r|}
\hline & & & & \multirow{4}{|c|}{ Cluster } \\
Code & Ownership & Location & $\begin{array}{c}\text { Number } \\
\text { of } \\
\text { obser- } \\
\text { vations }\end{array}$ & $\begin{array}{c}\mathbf{1} \\
\text { High-tech } \\
\text { manu- } \\
\text { facturing }\end{array}$ & $\begin{array}{c}\mathbf{2} \\
\text { Low-tech } \\
\text { manu- } \\
\text { facturing }\end{array}$ & $\begin{array}{c}\mathbf{3} \\
\text { High-tech } \\
\text { services }\end{array}$ & $\begin{array}{c}4 \\
\text { Low-tech } \\
\text { services }\end{array}$ \\
\hline T_CZ1 & $\begin{array}{l}\text { Greenfield } \\
\text { daughter }\end{array}$ & $\begin{array}{l}\text { Czech } \\
\text { Republic }\end{array}$ & 264 & 11.7 & 44.3 & 26.5 & 17.4 \\
\hline T_CZ2 & M\&A daughter & $\begin{array}{l}\text { Czech } \\
\text { Republic }\end{array}$ & 86 & 19.8 & 51.2 & 15.1 & 14.0 \\
\hline C_CZ & Control group & $\begin{array}{l}\text { Czech } \\
\text { Republic }\end{array}$ & 662 & 17.1 & 30.8 & 21.6 & 30.5 \\
\hline T_DE & Mother & Germany & 364 & 49.7 & 6.3 & 28.8 & 15.1 \\
\hline C_DE & Control group & Germany & 1,065 & 21.1 & 19.2 & 20.6 & 39.1 \\
\hline CZ & Subtotal & $\begin{array}{l}\text { Czech } \\
\text { Republic }\end{array}$ & 1,012 & 15.9 & 36.1 & 22.3 & 25.7 \\
\hline DE & Subtotal & Germany & 1,429 & 28.4 & 16.0 & 22.7 & 33.0 \\
\hline T & $\begin{array}{l}\text { Mother \& } \\
\text { daughter }\end{array}$ & Subtotal & 714 & 32.1 & 25.8 & 26.3 & 15.8 \\
\hline C & Control group & Subtotal & 1,727 & 19.6 & 23.7 & 21.0 & 35.8 \\
\hline
\end{tabular}

However, this does not seem to be the case in services, where the proportion of high-tech and low-tech operations comes out to be very similar for the mothers and the greenfield affiliates. M\&A daughters lag somehow behind in this respect, but even in this category, the high-tech cluster is more frequent than the low-tech one. This is in a sharp contrast with the control group, for which the low-tech cluster is significantly more populated. 
From this follows that the cross-border direct investment in the service sector, particularly in greenfield projects, is predominantly horizontal as the daughters tend to engage in a similar portfolio of activities in terms of technology, education, and skill intensity as the mother companies.

Overall, as a result if added together, firms located in Germany appear notably more advanced than those operating in the Czech Republic. This is primarily driven by differences in terms of the cluster classification in manufacturing, in which the Czech firms are clearly technologically inferior to their German counterparts. However, there is not that much difference in the service sector, where the proportion between firms classified as high-tech and low-tech is even slightly higher on the Czech side of the border. According to this data, therefore, the difference between both countries boils down to the low-skilled labour requirements of daughters in the manufacturing stratum of the economy.

\section{Regression Analysis}

Yet from descriptive tabulations, we can derive only preliminary conclusions because the observed patterns can be driven by a host of factors that are not properly accounted for. More confident statements can be derived from investigating the data in an econometric framework. In the next step, therefore, we estimate a probit model, in which the outcome is the classification of firms obtained from the cluster analysis represented by a dummy variable with the value 1 for the high-tech category and the value 0 for the low-tech cluster, while on the right-hand side is the size of the firms given by the log of employees, the age given by the log of years since the firm was established, a set of location and ownership dummies, for which the mothers represent the base category, and a set of industry dummies. ${ }^{4}$

The idea is that firms make a strategic choice to specialize in their respective cluster. Arguably, this is most relevant for the daughters because the mother companies generally decide on their specialization depending on a number of factors, including the global offshoring strategy of the corporation, the main motive for the investment, and the factor endowments of the location. In other words, the mothers are assumed to have a freedom to choose whether the daughter is limited to a low-tech operation primarily exploiting factor cost differences or whether the project develops into a complex, high-tech facility.

Table 5 gives the results. Since the cluster solution splits the sample by broad sectors, we estimate the model separately for each of them. In the first column are results for manufacturing, and in the second column are the results for the service sector. For comparing the magnitude of the estimated relationships, we report marginal effects derived at the mean of the other covariates. Specifically for the binary covariates, the

4 Because of data limitations, the industry dummies have been aggregated to 24 categories broadly following the 2-letter alphabetical structure of NACE, rev. 2 classification. More details on the definition of the categories are available from the authors upon request. 
marginal effect refers to the discrete change from the base level. For details on the maximum likelihood procedure see Stata (2009b).

Even after controlling for the size, age, and industry differences, the results generally confirm the interpretation proposed above. Both the greenfield and M\&A daughters are significantly less likely to be high-tech than the mothers in manufacturing, but there does not seem to be a statistically significant difference at the conventional levels in the service sector. The control groups are always significantly inferior to the mothers, but in terms of the estimated marginal effects, this is to a noticeably more extent the case in manufacturing than in services. Moreover, both types of affiliates appear technologically less sophisticated than the control groups in manufacturing, while the reverse tendency is detected in services; note that these differences are statistically significant at the $5 \%$ level except for the M\&A daughters in the service sector only.

According to expectations, there is a positive effect of size in manufacturing because of various scale economies in production. Large firms are in a much better position to finance, for example, their own R\&D department, which is the essential identification criterion of the high-tech manufacturing cluster. In contrast, size does not seem to be important in services because the potential for exploiting economies of scale is known to be considerably smaller; hence, it does not make much difference. Age represents factors that are a function of time including various learning effects such as learning by doing and other resources that accumulate gradually over the years. Again, this appears to be much more relevant in manufacturing than in the service sector.

Table 5

Results of a Probit Model

\begin{tabular}{|c|c|c|}
\hline \multirow[b]{3}{*}{ Dependent variable } & \multicolumn{2}{|c|}{ Cluster } \\
\hline & 1 and 2 & 3 and 4 \\
\hline & $\begin{array}{c}\text { High-tech } \\
\text { manufacturing }\end{array}$ & $\begin{array}{l}\text { High-tech } \\
\text { services }\end{array}$ \\
\hline Log of employees & $0.094(0.014)^{\star * *}$ & $-0.003(0.010)$ \\
\hline Log of age & $0.072(0.023)^{* * *}$ & $0.016(0.020)$ \\
\hline Greenfield daughter & $-0.642(0.050)^{* * *}$ & $-0.049(0.064)$ \\
\hline M\&A daughter & $-0.616(0.067)^{* * *}$ & $-0.124(0.108)$ \\
\hline Czech control group & $-0.460(0.042)^{* * *}$ & $-0.208(0.051)^{\star \star * *}$ \\
\hline German control group & $-0.391(0.039)^{* * *}$ & $-0.312(0.045)^{\star * *}$ \\
\hline Industry dummies & Included & Included \\
\hline Wald $\chi^{2}$ & $301.74^{* * *}$ & $191.51^{* * *}$ \\
\hline Log pseudolikelihood & -589.80 & -757.63 \\
\hline Pseudo $\mathbf{R}^{2}$ & 0.26 & 0.12 \\
\hline Number of observations & 1,150 & 1,267 \\
\hline
\end{tabular}

Note: Marginal effects at the mean of other explanatory variables are reported; robust standard errors in brackets; ${ }^{* * *},{ }^{* *}$, and * indicate significance at the 1,5 , and $10 \%$, respectively. 


\section{Conclusions}

Using unique micro evidence on technological, educational, and skill intensity of German mother companies and their daughters in the Czech Republic derived from the ReLOC survey, we identified, with the help of a cluster analysis, four main groups of firms that partition the sample in: i) High-tech manufacturers; ii) Low-tech manufacturers; iii) High-tech service providers; and iv) Low-tech service providers. A more detailed examination of the clustering by location and ownership of the firms and in the framework of a probit model revealed that the factor requirements of the daughters do not come out to be significantly different from the mothers in the service sector, from which we conclude that the dominant model of investment is horizontal, whereas there is a profound difference in this respect in manufacturing, which points to predominantly vertical investment in this sector.

Looking from the German perspective, the results indicate that on the one hand, in terms of the immediate impact on the labour market, cross-border investment is likely to influence the relative wages of skilled and unskilled workers and hence disrupt the market in manufacturing but not in the service sector. However, on the other hand, fears of hollowing out local innovation systems do not seem to be justified in manufacturing as technologically advanced activities remain concentrated near the headquarters, but there is the possibility that high-skilled intensive jobs are being transferred across the border in the service sector. Of course, the impact depends on whether the jobs are relocated from Germany or whether the investment projects generate new jobs not undertaken before in Germany.

From the Czech point of view, however, the results suggest that the cross-border investment in manufacturing generates jobs for low-skilled workers, possibly reducing unemployment in this segment of the labour market, but the investment projects fall short of expectations as far as their contribution to technological upgrading is concerned as they predominantly deepen specialization of the local economy in low-tech jobs. Somewhat surprisingly cross-border investment in the service sector appears much more promising in terms of stimulating the upgrading process. It is important to realize in this respect that the deepening fragmentation of production makes a lock-in situation in the low-cost edge of global production networks more likely than before. But the ultimate welfare impact on both sides of the border that begs for closer scrutiny clearly goes beyond the scope of this paper.

Admittedly, this points to the main limitations of the paper. First and foremost, it would have been of interest to analyze the impact of these patterns on productivity growth. This requires, however, integrating the ReLOC survey data with information from other sources, most notably with balance sheet data and employment statistics, which exists at least for a subsample of the firms, and hence, this is a feasible next step. It may also be useful to analyze the dynamic aspects of the issues under consideration, something that may be possible if the ReLOC survey is repeated in the coming years. 


\section{References}

Arndt, S. W., Kierzkowski, H. (2001), Fragmentation: New Production Patterns in the World Economy. Oxford: Oxford University Press.

Acemoglu, D., Autor, D. (2011), "Skills, Tasks and Technologies: Implications for Employment and Earnings“ in Ashenfelter. O., Card, D., eds., Handbook of Labor Economics. Vol. 4b, Amsterdam: Elsevier, pp. 1043-1171.

Barba Navaretti, G. B., Venables, A. J. (2004), Multinational Firms in the World Economy. Princeton: Princeton University Press.

Blomström, M., Kokko, A. (1998), "Multinational Corporations and Spillovers." Journal of Economic Surveys, Vol. 12, No. 2, pp. 247-278.

Brainard, L. S. (1993), "An Empirical Assessment of the Factor Proportions Explanation of Multinational Sales." NBER Working Paper No. 4583.

Buch, C., Kleinert, J., Lipponer, A., Toubal, F. (2005), "Determinants and Effects of Foreign Direct Investment: Evidence from German Firm-Level Data." Economic Policy, Vol. 20, No. 41, pp. 52-110.

Buch, C. M., Schnitzer, M., Arndt, C., Kesternich, I., Mattes, A., Mugele, C., Strotmann, H. (2007), "Analyse der Beweggründe, der Ursachen und der Auswirkungen des so genannten Offshoring auf Arbeitsplätze und Wirtschaftsstruktur in Deutschland." Tübingen / München: IAW / LMU.

Calinski, T., Harabasz, J. (1974), "A Dendrite Method for Cluster Analysis." Communications in Statistics, Vol. 3, No. 1, pp. 1-27.

Cantwell, J. (1995), "The Globalization of Technology: What Remains of the Product Cycle Model?" Cambridge Journal of Economics, Vol. 19, No. 1, pp. 155-174.

Caves, R. E. (1971), "International Corporations: The Industrial Economics of Foreign Investment." Economica, Vol. 38, No. 149, pp. 1-27.

CNB (2012), Foreign Direct Investment in 2010. Prague: Czech National Bank.

CZSO (2012), Zahranični obchod s Německem [External trade with Germany]. Prague: Czech Statistical Office.

Deutsche Bundesbank (2012), Foreign Direct Investment Stock Statistics: Special Statistical Publication, 10 April 2012. Frankfurt: Deutsche Bundesbank.

Duda, R. O., Hart, P. E., Stork, D. G. (2001), Pattern Classification and Scene Analysis, 2nd Ed. New York: Wiley.

Dunning, J. H. (1981), "Explaining the International Direct Investment Position of Countries: Towards a Dynamic or Developmental Approach." Weltwirtschaftliches Archiv, Vol. 117, No. 1, pp. 30-64.

Dunning, J., Narula, R. (1995), "The R\&D Activities of Foreign Firms in the United States." International Studies of Management \& Organization, Vol. 25, No. 1-2, pp. 39-73.

Ernst, D., Kim, L. (2002), "Global Production Networks, Knowledge Diffusion, and Local Capability Formation." Research Policy, Vol. 31, No. 8-9, pp. 1417-1429.

Eurostat (2012), Eurostat on-line. Luxembourg: Eurostat (download 19. 9. 2012).

Faeth, I. (2009), "Determinants of Foreign Direct Investment - A Tale of Nine Theoretical Models." Journal of Economic Surveys, Vol. 23, No. 1, pp. 165-196.

Feenstra, R. (1998), "Integration of Trade and Disintegration of Production in the Global Economy." Journal of Economic Perspectives, Vol. 12, No. 4, pp. 31-50.

Fujita, M., Krugman, P. R., Venables, A. J. (1999), The Spatial Economy. Cities, Regions, and International Trade. Cambridge: MIT Press.

Gauselmann, A., Knell, M., Stephan, J. (2011), "What Drives FDI in Central-Eastern Europe? Evidence from the IWH-FDI-Micro Database." Post-Communist Economies, Vol. 23, No. 3, 343-357.

Gereffi, G., Humphrey, J., Sturgeon, T. (2005), "The Governance of Global Value Chains." Review of International Political Economy, Vol. 12, No. 1, pp. 105-128. 
Görg, H., Greenaway D. (2004), "Much Ado about Nothing? Do Domestic Firms really Benefit from Foreign Direct Investment?" The World Bank Research Observer, Vol. 19, No. 2, pp. 171-197.

Görg, H., Mühlen, H., Nunnenkamp, P. (2010), "Firm Heterogeneity, Industry Characteristics and Types of FDI: The Case of German FDI in the Czech Republic." Aussenwirtschaft, Vol. 65, No. 3, pp. 273-295.

Günther, J., Gauselmann, A., Marek, P., Stephan, J., Jindra, B. (2011), "An Introduction to the IWH FDI Micro Database." Schmollers Jahrbuch, Vol. 131, No. 3, pp. 529-546.

Havranek, T., Irsova, Z. (2011), "Estimating Vertical Spillovers from FDI: Why Results Vary and What the True Effect Is." Journal of International Economics, Vol. 85, No. 2, pp. 234-244.

Hecht, V., Litzel, N., Schäffler, J. (2013), "The ReLOC Project - Method Report for Implementing a Cross-Border Company Survey in Germany and the Czech Republic. "IAB Research Report. Nürnberg: Institute for Employment Research (IAB), 04/2013.

Helpman, E. (1984), "A Simple Theory of Trade with Multinational Corporations." Journal of Political Economy, Vol. 92, No. 3, pp. 451-471.

Helpman, E., Krugman, P. (1985), Market Structure and Foreign Trade. Cambridge, MIT Press.

Kogut, B. (1985), "Designing Global Strategies: Comparative and Competitive Value-Added Chains." Sloan Management Review, Vol. 26, No. 4, pp. 15-28.

Kogut, B., Zander, I. (1993), "Knowledge of the Firm and the Evolutionary Theory of the Multinational Corporation." Journal of International Business Studies, Vol. 24, No. 4, pp. 625-645.

Krugman, P. (1995), "Growing World Trade: Causes and Consequences." Brookings Papers on Economic Activity, Vol. 25, No. 1, pp. 327-362.

Kuemmerle, W. (1997), "Building Effective R\&D Capabilities Abroad." Harvard Business Review, Vol. 75, No. 3, pp. 61-70.

Marin, D., Lorentowicz, A., Raubold, A. (2003), "Ownership, Capital or Outsourcing: What Drives German Investment in Eastern Europe?" in Herrmann, H., Lipsey, R., ed., Foreign Direct Investment in the Real and Financial Sector in Industrial Countries. Berlin: Springer-Verlag, pp. 147-163.

Marin, D. (2006), "A New international division of Labor in Europe: Outsourcing and Offshoring to Eastern Europe." Journal of the European Economic Association, Vol. 4, No. 2-3, pp. 612-622.

Markusen, J. R. (1984), "Multinationals, Multi-Plant Economies and the Gains from Trade." Journal of International Economics, Vol. 16, No. 3-4, pp. 205-226.

Markusen, J. R., Venables, A. J. (1998), "Multinational Firms and the New Trade Theory." Journal of International Economics, Vol. 46, No. 2, pp. 183-203.

OECD (2002), Frascati Manual: Proposed Standard Practice for Surveys on Research and Experimental Development, $6^{\text {th }}$ Ed. Paris: OECD.

Protsenko, A. (2003), "Vertical and Horizontal Foreign Direct Investments in Transition Countries." Mimeo, doctoral dissertation, Ludwig-Maximilians-Universität München.

Stancik, J. (2007), "Horizontal and Vertical FDI Spillovers." CERGE-EI Working Paper No. 340.

Stata (2009a), Stata Multivariate Statistics Reference Manual, Release 11. College Station (Texas): StataCorp LP.

Stata (2009b), Stata Base Reference Manual, Release 11. College Station (Texas): StataCorp LP.

Vernon, R. (1966), "International Investment and International Trade in Product Cycle." Quarterly Journal of Economics, Vol. 80, No. 2, pp. 190-207. 